\title{
The evaluation of zinc and copper content in tooth enamel without any pathological changes - an in vitro study
}

This article was published in the following Dove Press journal: International Journal of Nanomedicine

\author{
Elzbieta Klimuszko' \\ Karolina Orywal ${ }^{2}$ \\ Teresa Sierpinska' \\ Jarosław Sidun ${ }^{3}$ \\ Maria Golebiewska' \\ 'Department of Prosthetic Dentistry, \\ Medical University of Bialystok, \\ Bialystok, Poland; ${ }^{2}$ Laboratory of \\ Biochemical Diagnostics Department, \\ Medical University of Bialystok, \\ Bialystok, Poland; ${ }^{3}$ Department of \\ Materials Science and Biomedical \\ Engineering, Bialystok University of \\ Technology, Bialystok, Poland
}

Objectives: The objectives of the study were to evaluate the content of copper and zinc in individual layers of tooth enamel and to analyze the relationships between the study minerals in individual layers of tooth enamel.

Patients and methods: Fifteen human permanent teeth were cut off every $150 \mu \mathrm{m}$ alongside the labial surface. Acid biopsy of each layer was performed. The zinc content was determined using the air-acetylene flame method. The copper content was determined using the electrothermal technique with argon.

Results: The mean zinc concentrations increased significantly starting from the outer enamel surface, with the maximum concentration in the 150-300 $\mu \mathrm{m}$ layer. The mean copper concentrations increased substantially from the outer enamel surface to a depth of $150 \mu \mathrm{m}$, and then a slight downward trend of this mineral levels was seen, down to a depth of $450 \mu \mathrm{m}$. Strong positive correlation was found between the zinc and copper concentrations at depths of 150-300, 450-600 and 600-750 $\mu \mathrm{m}$

Conclusion: The levels of zinc and copper in the outer enamel layers may have an effect on the increased content of unipolar minerals at deeper enamel layers. The content of the study elements determined may reflect the process of mineralization and maturation of enamel in the pre-eruption period.

Keywords: zinc, copper, enamel

\section{Introduction}

Enamel is the tissue covering the entire clinical crown of a tooth. Its spatial arrangement and mineralization make it the hardest tissue in the human body (4-5 in the Mohs' scale). ${ }^{1}$ Enamel is a dead composition and has no ability to regenerate, repair and rebuild itself. ${ }^{1-4}$ Due to its unique structure, it serves as a protective barrier against chemical, thermal and biologic agents to dentin and pulp..$^{5-9}$ An increasing number of studies suggest that the resistance of enamel to external agents depends on its chemical composition and structure which is formed in the process of odontogenesis. ${ }^{10,11}$

Zinc and copper are potential components related to the formation of and changes within the enamel matrix. Zinc is one of the most potent inhibitors of serine proteases, including kallikrein $4{ }^{12}$ Zinc is also contained in alkaline phosphatase and plays an important role in the activation of this enzyme. The majority of zinc is accumulated in teeth directly after their eruption, and protein binding is a mechanism which determines the zinc level. Moreover, it is a component of some metalloproteinases, including enamelysin and transcription factors Krox 25 and Krox $26 .^{13}$ This mineral also interacts with hydroxyapatite through the absorption to the crystal surface and its
Correspondence: Teresa Sierpinska Department of Prosthetic Dentistry, Medical University of Bialystok, 24a M. Sklodowskiej-Curie Str., I5-276 Bialystok, Poland

Tel +48 8574645858

Fax +48 857447030

Email teresasierpinska@gmail.com
International Journal of Nanomedicine 20|8:|3 |257-|264

1257

Dovepress f 10

http://dx.doi.org/1 $0.2147 / 1$ N N.S15522 (c) (i) (5) 2018 Klimuszko et al. This work is published and licensed by Dove Medical Press Limited. The full terms of this license are available at https://www.dovepress.com/terms.php cC. hereby accept the Terms. Non-commercial uses of the work are permitted without any further permission from Dove Medical Press Limited, provided the work is properly attributed. For permission for commercial use of this work, please see paragraphs 4.2 and 5 of our Terms (https://www.dovepress.com/terms.php). 
incorporation in the crystal lattice. Low concentrations of this element modify or inhibit remineralization; however, they also significantly reduce enamel dissolution. ${ }^{14}$ The concentration of zinc in the ameloblast nucleus increases during the enamel formation and reaches the highest level in the early stage of enamel maturation. ${ }^{15}$

Copper has a significant impact on the acid solubility of enamel, which is a basic process in the development of dental caries and erosion. ${ }^{11,16}$ The dissolution of enamel is reduced in the presence of copper ions. The ability to precipitate a protective copper phosphate phase on the tooth surface decreases and inhibits demineralization through stabilization of the crystal lattice of enamel surface. ${ }^{16}$ Furthermore, copper exerts a cariostatic effect through inhibition of bacterial growth and bacterial metabolic enzymes. ${ }^{17}$

There is a metabolic relationship between copper and zinc. Proper functioning of the body is possible at a specific cation concentration ratio of these two minerals in the extracellular space. ${ }^{18}$ Zinc and copper exert antagonistic effects through the competitive mechanism involving competition for absorption between these bioelements. Predominant concentration of one of them results in the displacement of the second one, causing its deficiency in the body. Taking zinc doses that are much higher than a daily reference value over long periods may lead to copper absorption disorders. In addition, many other effects, which were initially attributed to excess copper in the body, are caused by copper deficiency induced by high doses of this metal. On the other hand, copper deficiency increases zinc toxicity. This relationship might apply to tooth enamel which is formed in the process of amelogenesis. ${ }^{19}$

Considering the fact that zinc and copper may influence the resistance of enamel to wear, the objectives of the paper were to evaluate copper and zinc content in individual layers of tooth enamel and to analyze the relationships between the study minerals in individual layers of tooth enamel.

\section{Patients and methods Study material}

Fifteen fully developed human permanent teeth (central upper incisors) without any visible pathological changes were used for this study. The teeth were extracted due to mechanical damage in the area of alveolar process or changes in periodontium. They were obtained from donors between 18 and 21 years of age. They were prepared by strictly adhering to the requirements, in accordance with ISO/TS 11405:2015. ${ }^{20}$ The teeth were frozen at $-8^{\circ} \mathrm{C}$, and then, the day before examination, they were placed in distilled water at $4^{\circ} \mathrm{C}$ in sterile, securely closing 1.5 mL Safe-Lock tubes (EppendorfNetheler-Hinz, Hamburg, Germany). The tubes were marked successively with letters from A to $\mathrm{O}$.

All teeth used in this research were obtained from the Bank of Teeth, University of Bern, School of Dental Medicine, Department of Preventive, Restorative and Pediatric Dentistry, Switzerland. All patients had provided written informed consent for the use of the extracted teeth for future research. The Local Ethical Committee of the Medical University of Bialystok, Poland reviewed the research protocol and granted exemption due to teeth derivation.

All methods were applied in accordance with relevant guidelines and regulations.

\section{Study design \\ Longitudinal cuts on the labial surface of the teeth studied}

Each of the teeth studied was placed fixedly in the Microm HM $355 \mathrm{~S}$ instrument (Microm International $\mathrm{GmbH}$ ) equipped with a cutting knife made of very hard tungsten carbide WC. The cutting was started at the point of contact of the knife with the studied tooth surface. Due to the high hardness of enamel, the dental tissue was cut at a speed of $1 \mathrm{~mm} / \mathrm{s}$. The microtome allows cutting with a thickness of $0.5-150 \mu \mathrm{m}$ and at a speed of $0-430 \mathrm{~mm} / \mathrm{s}$. Tooth enamel was cut off every $150 \mu \mathrm{m}$ alongside the labial surface to obtain the material from seven successive layers for further testing. The central part of each cut was located in the middle part of the labial surface where the study tooth equator ran. The cutting plane and the distance between successive cuts were determined on the basis of the course and distance between Retzius lines, and the daily amount of deposited enamel was averaged. $^{21}$

\section{Acid biopsy}

The first acid biopsy was performed on the labial surfaces of the teeth studied before they were placed in the Microm HM $355 \mathrm{~S}$ instrument and the first cuts were made.

The material obtained after cutting each enamel layer out was placed on a sterile plate (microscopic cover glass; Menzel, Bielefeld, Germany). Four Whatmann filter paper circles, of diameter $2 \mathrm{~mm}$, containing no chemical elements were placed on the surface of each enamel specimen obtained. The circles were saturated with $0.1 \mathrm{~mL}$ of perchloric acid standard solution $\left(\mathrm{HClO}_{4}\right) \quad 0.1 \mathrm{~mol} / \mathrm{L}$ manufactured by Chempur (Piekary Śląskie, Poland). The volume of perchloric acid needed for the study was measured out with a micropipette (Eppendorf Varipette 4710; Eppendorf-Netheler-Hinz) 
with a plastic exchangeable tip from the same manufacturer. The enamel specimens were digested for 60 seconds with acid applied perpendicularly to the study specimen, directly on paper circles.

All obtained biopsy specimens were put into sterile, securely closing, plastic, $1.5 \mathrm{~mL}$ Safe-Lock tubes (EppendorfNetheler-Hinz). Apart from marking with a letter from A to $\mathrm{O}$ (designation of the study tooth), each tube was assigned a successive number corresponding to the depth of the study layer: 00 - for a specimen collected from the labial surface before the cuts were made, $0-(0-150 \mu \mathrm{m}), 1-(150-300 \mu \mathrm{m})$, $2-(300-450 \mu \mathrm{m}), 3-(450-600 \mu \mathrm{m}), 4-(600-750 \mu \mathrm{m})$, $5-(750-900 \mu \mathrm{m})$ and $6-(900-1050 \mu \mathrm{m})$. The enamel cuts and acid biopsies were performed at the Department of Materials and Biomedical Engineering of the University of Technology.

\section{Specimen mineralization}

The specimens were submitted to the Department of Biochemical Diagnostics. Paper circles were shortly subjected to mineralization in $1.5 \mathrm{~mL}$ concentrated $\mathrm{HNO}_{3}$ solution and $0.5 \mathrm{~mL}$ ultrapure water. The mineralization was performed in the Uniclever II microwave mineralizer (Plazmatronika, Wrocław, Poland).

\section{Atomic absorption spectrometry}

The zinc and copper content was determined using the Z-5000 polarized Zeeman atomic absorption spectrophotometer (Hitachi Ltd., Tokyo, Japan). The concentrations of both elements were determined on the basis of the calibration curve determined by the instrument for a particular element and in working conditions recommended by the instrument manufacturer. All the results are the mean value from three measurements. The precision of the assay is expressed by relative $\mathrm{SD}(\% \mathrm{RSD})$, which was $<6 \%$ for every tested sample. The zinc content was determined using the flame method with an air-acetylene flame. Working calibration curve was made using measurements of working standard solutions $(0.5,1.0$ and $1.5 \mathrm{mg} / \mathrm{L}$ of zinc) prepared by dilution of standard for atomic spectrometry (zinc concentration 1,000 mg/L; Sigma-Aldrich). Single-element hollow-cathode lamp for zinc, standard atomizer and fuel flow $2 \mathrm{~L} / \mathrm{min}$ were used. The copper content was determined using the electrothermal method with argon. Single-element hollowcathode lamp for copper, cuvette type-tube A and gas flow $30 \mathrm{~mL} / \mathrm{min}$ were used. Working calibration curve was made using measurements of working standard solutions $10.0 \mu \mathrm{g} / \mathrm{L}$, $15.0 \mu \mathrm{g} / \mathrm{L}$, and $20.0 \mu \mathrm{g} / \mathrm{L}$ of copper), made by dilution of standard for atomic spectrometry (copper concentration 1,000 $\mu \mathrm{g} / \mathrm{L}$; Sigma-Aldrich).

\section{Statistical analysis}

Statistical analysis of the study variables was performed. All parameters analyzed were determined to be normally distributed. In the case of quantitative attributes, the measures of central tendency and variability were calculated (ie, arithmetic mean and SD). The data for the studied parameters were compared between the groups using the Student's one-tailed $t$-test for unequal variances. The strengths of the relationships between the pairs of measurable parameters were determined using Pearson's correlation coefficient, and its significance was assessed using Student's $t$-test. Differences and relationships were considered to be statistically significant at $p<0.05$. Statistical analysis of the results obtained was performed using Statistica, v. 10.0.PL.

\section{Results Evaluation of zinc $(\mathrm{Zn})$ content in successive enamel layers of the teeth studied}

The highest mean zinc concentration $(89.33024 \mu \mathrm{g} / \mathrm{L})$ was obtained in a layer between 150 and $300 \mu \mathrm{m}$ (SD 55.74761). The lowest mean zinc concentration $(36.67324 \mu \mathrm{g} / \mathrm{L})$ was found on the outer enamel surface of the teeth studied (SD 12.34276). The minimum concentration of this mineral $(20.12321 \mu \mathrm{g} / \mathrm{L})$ was recorded at a depth of $0-150 \mu \mathrm{m}$.

The mean zinc concentrations increased significantly starting from the outer enamel surface, with the maximum concentration obtained in the 150-300 $\mu \mathrm{m}$ layer. Then, a gradual decrease in mean concentrations of this element was seen at a depth between 300 and $900 \mu \mathrm{m}$. The mean concentrations of this mineral increased again to a value of $72.2125 \mu \mathrm{g} / \mathrm{L}(\mathrm{SD} 52.24011)$ at a depth between 900 and $1050 \mu \mathrm{m}$. A graphical presentation of zinc distribution at the individual enamel depths is shown in Figure 1.

The relationships between the zinc levels in individual enamel layers taking into consideration the Pearson's linear correlation coefficient and the significance level $(p)$ for a particular correlation are presented in Table 1 . Statistically significant $(p<0.05)$ strong positive correlation between the zinc levels was found at the following depths: $0-150$ and 450-600 $\mu \mathrm{m}$ (Zn0-Zn3); 150-300 and 300-450 $\mu \mathrm{m}$ (Zn1-Zn2); 150-300 and 450-600 $\mu \mathrm{m}(\mathrm{Zn1}-\mathrm{Zn3}) ; 150-300$ and 600-750 $\mu \mathrm{m}$ (Zn1-Zn4); 450-600 and 600-750 $\mu \mathrm{m}$ (Zn3-Zn4); 450-600 and 750-900 $\mu \mathrm{m}$ (Zn3-Zn5); 600-750 and 750-900 $\mu \mathrm{m}$ (Zn4-Zn5) and 600-750 and 900-1050 $\mu \mathrm{m}$ (Zn4-Zn6). 


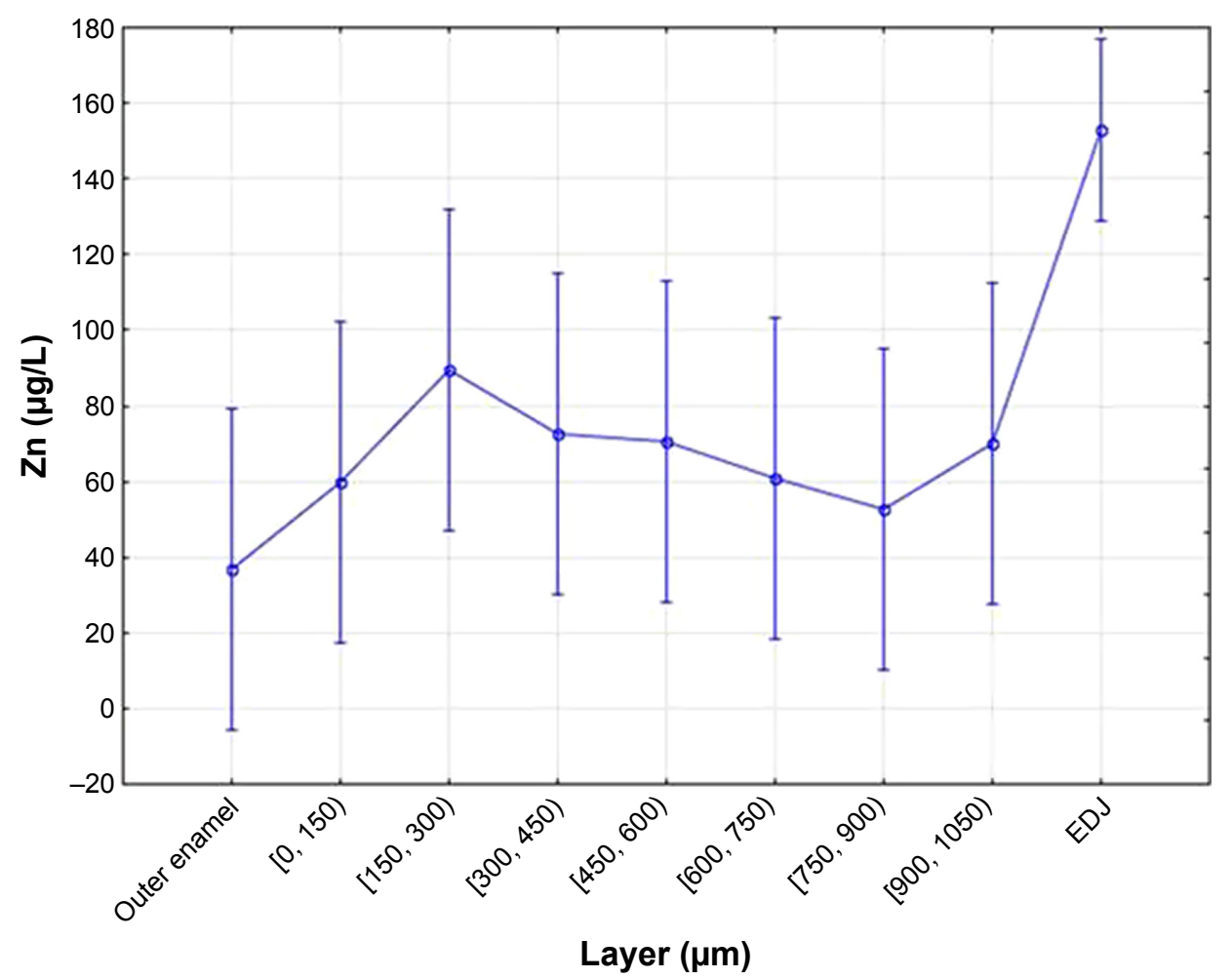

Figure I Zinc content distribution in individual enamel layers (00-outer layer, 0- [0, I50) $\mu \mathrm{m}, \mathrm{I}-[150,300) \mu \mathrm{m}, 2-[300,450) \mu \mathrm{m}, 3-[450,600) \mu \mathrm{m}, 4-[600,750) \mu \mathrm{m}$, 5- $[750,900) \mu \mathrm{m}, 6-[900,1050) \mu \mathrm{m}$, and EDJ).

Abbreviation: EDJ, enamel-dentin junction.

\section{Evaluation of copper $(\mathrm{Cu})$ content in successive enamel layers of the teeth studied}

The highest mean copper concentration $(20.98211 \mu \mathrm{g} / \mathrm{L})$ was obtained at a depth of 450-600 $\mu \mathrm{m}$ (SD 12.20001). The maximum concentration of this mineral $(58.72213 \mu \mathrm{g} / \mathrm{L})$ was noted at the same depth. The lowest mean copper concentration $(10.42267 \mu \mathrm{g} / \mathrm{L})$ was found on the outer enamel surface of the teeth studied (SD 5.53966), where the minimum concentration of this element $(4.13032 \mu \mathrm{g} / \mathrm{L})$ was noted as well.

The mean copper concentrations increased significantly starting from the outer enamel surface to a depth of $150 \mu \mathrm{m}$,

Table I Relationships between the Zn levels in particular enamel layers

\begin{tabular}{lll}
\hline$Z n$ & $\begin{array}{l}\text { Pearson's linear } \\
\text { correlation coefficient }\end{array}$ & p-value \\
\hline$Z n 0-Z n 3$ & 0.5879 & 0.021 \\
$Z n 1-Z n 2$ & 0.5502 & 0.034 \\
$Z n 1-Z n 3$ & 0.5948 & 0.019 \\
$Z n 1-Z n 4$ & 0.638 & 0.01 \\
$Z n 3-Z n 4$ & 0.5722 & 0.026 \\
$Z n 3-Z n 5$ & 0.5274 & 0.043 \\
$Z n 4-Z n 5$ & 0.5394 & 0.038 \\
$Z n 4-Z n 6$ & 0.6072 & 0.016 \\
\hline
\end{tabular}

and then a slight downward trend was seen in this mineral level, down to a depth of $450 \mu \mathrm{m}$. The mean copper concentration increased again at a depth between 450 and $600 \mu \mathrm{m}$, and the maximum mean value was obtained in this layer. A gradual decrease in the content of this mineral was observed at a depth between 600 and $1050 \mu \mathrm{m}$. A graphical presentation of copper distribution at particular enamel depths is shown in Figure 2.

The relationships between the copper levels in individual enamel layers taking into consideration the Pearson's linear correlation coefficient and the significance level $(p)$ for a particular correlation are presented in Table 2. Statistically significant $(p<0.05)$ strong positive correlation between the copper levels was found at the following depths: $0-150$ and 600-750 $\mu \mathrm{m}(\mathrm{Cu} 0-\mathrm{Cu} 4) ; 0-150$ and 900-1050 $\mu \mathrm{m}$ (Cu0-Cu6); -600-750 and 750-900 $\mu \mathrm{m}(\mathrm{Cu} 4-\mathrm{Cu} 5)$ and 600-750 and 900-1050 $\mu \mathrm{m}(\mathrm{Cu} 4-\mathrm{Cu} 6)$.

\section{Analysis of relationships between the $\mathrm{Zn}$ content and $\mathrm{Cu}$ content in individual enamel layers of the teeth studied}

The relationships between the copper content and zinc content in particular enamel layers taking into consideration the Pearson's linear correlation coefficient and the significance level $(p)$ for a particular correlation are presented in Table 3. 


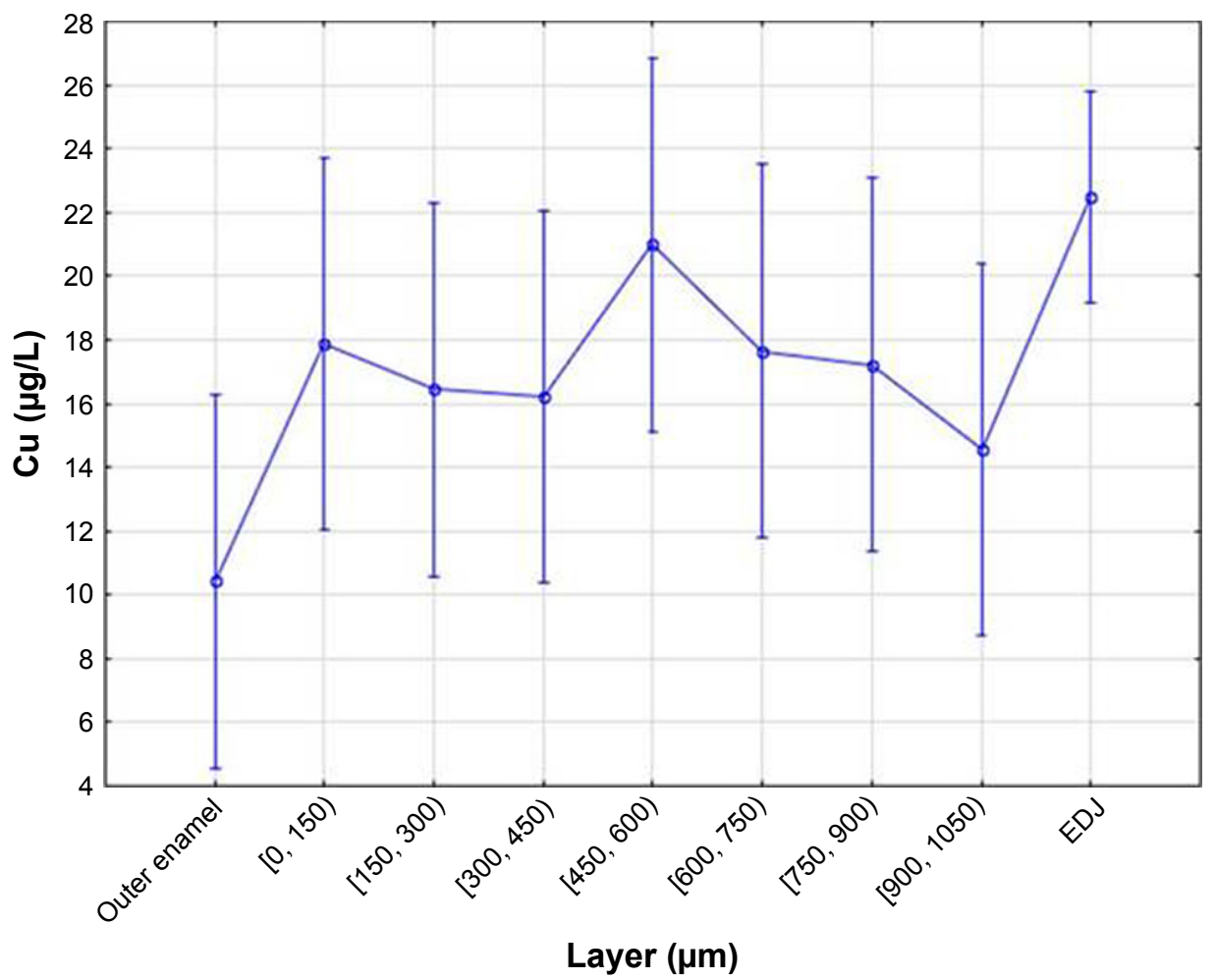

Figure 2 Copper content distribution in particular enamel layers (00-outer layer, 0- $[0,150) \mu \mathrm{m}, 1-[150,300) \mu \mathrm{m}, 2-[300,450) \mu \mathrm{m}, 3-[450,600) \mu \mathrm{m}, 4-[600,750) \mu \mathrm{m}$, 5- $[750,900) \mu \mathrm{m}, 6-[900,1050) \mu \mathrm{m}$, and EDJ).

Abbreviation: EDJ, enamel-dentin junction.

Statistically significant $(p<0.05)$ strong positive correlation between the zinc and copper concentrations was found at the following depths: 150-300 $\mu \mathrm{m}$ (Zn1-Cu1); 450-600 $\mu \mathrm{m}$ (Zn3-Cu3) and 600-750 $\mu \mathrm{m}(\mathrm{Zn} 4-\mathrm{Cu} 4)$.

\section{Discussion}

A detailed understanding of the development of tooth structure and its mineral composition plays an important role in the evaluation of enamel mineralization disorders, because information about the metabolic and physiological processes occurring during ontogenetic development is contained in the structure of this tissue. ${ }^{22}$ The absence of some minerals in the tooth tissue may both affect the content of other minerals and result in a greater tooth vulnerability to dental caries and other pathological agents. ${ }^{23}$ Marked differences in the chemical composition within different areas of the

Table 2 Relationships between the Cu levels in particular enamel layers

\begin{tabular}{lll}
\hline $\mathrm{Cu}$ & $\begin{array}{l}\text { Pearson's linear } \\
\text { correlation coefficient }\end{array}$ & $\boldsymbol{p}$-value \\
\hline $\mathrm{Cu} 0-\mathrm{Cu} 4$ & 0.05742 & 0.025 \\
$\mathrm{Cu} 0-\mathrm{Cu} 6$ & 0.5262 & 0.044 \\
$\mathrm{Cu} 4-\mathrm{Cu} 5$ & 0.08582 & 0.00 \\
Cu4-Cu6 & 0.6648 & 0.007 \\
\hline
\end{tabular}

same tooth may also occur depending on the distance to the tooth surface. Therefore, conducting studies that evaluate the content of zinc and copper at different enamel depths seems to be justified.

A decision was taken to evaluate the levels of zinc and copper as they are directly related to the formation of and changes within the enamel matrix. Human teeth that are free from pathological processes and stored in conditions allowing for the evaluation and analysis of enamel mineral composition have been used in in vitro studies. ${ }^{20}$ The use of acid biopsy technique enables to obtain reliable results. However, it should be kept in mind that the content of a particular mineral in a biopsy specimen may indicate a low enamel vulnerability to dissolution under the influence of acid applied, or the actual mineral content in the enamel. ${ }^{24}$

Literature data demonstrate that the zinc concentration within the entire enamel is around $115 \mu \mathrm{g} / \mathrm{g}$, while it is around

Table 3 Relationships between the $\mathrm{Zn}$ and $\mathrm{Cu}$ levels in particular enamel layers

\begin{tabular}{lll}
\hline $\mathrm{Zn} / \mathrm{Cu}$ & $\begin{array}{l}\text { Pearson's linear } \\
\text { correlation coefficient }\end{array}$ & P-value \\
\hline $\mathrm{ZnI}-\mathrm{CuI}$ & 0.6019 & 0.018 \\
$\mathrm{Zn3}-\mathrm{Cu} 3$ & 0.5255 & 0.044 \\
$\mathrm{Zn} 4-\mathrm{Cu} 4$ & 0.6615 & 0.007 \\
\hline
\end{tabular}


$1,000 \mu \mathrm{g} / \mathrm{L}$ in the superficial layers of enamel. ${ }^{25}$ Other studies have shown that the zinc content on the surface of tooth enamel free from pathological changes is $0.08 \mathrm{mg} / \mathrm{L} .{ }^{11} \mathrm{In}$ this paper, a mean zinc concentration of $36.67021 \mu \mathrm{g} / \mathrm{L}$ was noted on the enamel surface of the teeth studied, while the mean concentration of this mineral for the entire enamel was $64.0852 \mu \mathrm{g} / \mathrm{L}$. There are reports showing that the zinc enamel content decreases over the years. A zinc enamel content of $503.31 \mathrm{mg} / \mathrm{kg}$ was observed in the group of 20-year olds, and only $211.67 \mathrm{mg} / \mathrm{kg}$ was found in the group of 70-year olds. Changing zinc levels may be related to its intense participation in the mineralization processes of particular enamel layers, which decrease with age. Studies demonstrating that the concentration of zinc in the ameloblast nucleus increases during enamel formation and achieves the highest level in the early stage of enamel maturation have also been reviewed. ${ }^{15}$

The analysis carried out showed that with increasing zinc content at a depth between 0 and $150 \mu \mathrm{m}(20.12321 \mu \mathrm{g} / \mathrm{L})$, the zinc content at a depth of 450-600 $\mu \mathrm{m}(70.67024 \mu \mathrm{g} / \mathrm{L})$ increased. The same relationship was found at depths of 150-300 $\mu \mathrm{m}(89.33221 \mu \mathrm{g} / \mathrm{L})$ and 300-750, 450-600 and 600-900 $\mu \mathrm{m}$, as well as 600-750 $\mu \mathrm{m}(60.67342 \mu \mathrm{g} / \mathrm{L})$ and $750-1050 \mu \mathrm{m}$. In view of the above, it may be assumed that if the zinc level is established in the enamel development stage, then the content of this element in layers that undergo mineralization first affects its content in deeper layers.

According to the available literature data, the copper content of the enamel is $2-6 \mu \mathrm{g} / \mathrm{g} .{ }^{17}$ There are also reports that the mean copper concentration on the enamel surface free from pathological changes is $36.67 \mu \mathrm{g} / \mathrm{L} .{ }^{11}$ However, the tests carried out as part of the paper showed that the lowest copper content $(10.42267 \mu \mathrm{g} / \mathrm{L})$ was found on the enamel surface of the teeth studied, while the highest content $(20.98211 \mu \mathrm{g} / \mathrm{L})$ was found at a depth of $450-600 \mu \mathrm{m}$. The mean copper content for the entire enamel was $16.4182 \mu \mathrm{g} / \mathrm{L}$. It was substantiated in the paper that with increasing copper content at a depth of $0-150 \mu \mathrm{m}(17.87221 \mu \mathrm{g} / \mathrm{L})$, the copper concentrations at depths of 600-750 $\mu \mathrm{m}(17.64533 \mu \mathrm{g} / \mathrm{L})$ and $900-1050 \mu \mathrm{m}(14.55133 \mu \mathrm{g} / \mathrm{L})$ increased. The same relationship was observed between the copper concentrations at depths of 600-750 and 750-1050 $\mu \mathrm{m}$. Therefore, the copper content in layers that undergo mineralization first is likely to affect its content in deeper layers.

The metabolic relationship between zinc and copper has been documented. Studies by Sierpińska at al showed higher zinc content $(0.14 \mathrm{mg} / \mathrm{L})$ and lower copper content $(22.03 \mu \mathrm{g} / \mathrm{L})$ on the surface of teeth with pathological wear compared to the teeth free from visible pathological changes. This disproportion was even more marked in people with nearly all teeth featuring advanced wear. A significant difference in zinc and copper content depending on the degree of tooth wear was observed as well. ${ }^{11}$ It suggests that a higher degree of tooth wear is closely related to a higher zinc content and lower copper content in the enamel. In view of the antagonistic effects of these minerals, it should be expected that there is a correlation between an increase in copper content and a decrease in zinc content. ${ }^{24}$ However, this hypothesis has not been confirmed in the conducted study. It was found that with increasing zinc content, the copper content increased at depths of 150-300 and 450-750 $\mu \mathrm{m}$. Since the teeth with pathological changes (pathological wear) showed considerable differences in the zinc and copper content as compared to healthy teeth, it may be assumed that concentrations in the teeth free from pathological changes that were determined in the study carried out indicate normal enamel mineralization process in the pre-eruption period.

Environmental exposure to zinc and copper seems to be important. The highest zinc concentration observed at a depth of 150-300 $\mu \mathrm{m}$ may be related to its presence in the environment. The composition and properties of the outermost enamel layer coming into contact with the saliva are likely to be modified by the contact activity of copper ions during the post-eruptive maturation of enamel and later on. ${ }^{26}$ Taking into consideration the mechanism of action of copper ions and their influence on enamel, this effect is certainly desirable. There are studies showing that $1.25 \mathrm{mmol} / \mathrm{L}$ copper ions reduce the solubility of human enamel by $40 \%$ in vitro. ${ }^{27}$ Brookes et al found that $10 \mathrm{mmol} / \mathrm{L}$ copper ions inhibit phosphate loss from the enamel surface by $60 \%-70 \%$, and mineral dissolution is reduced by $50 \%$ at the copper ion concentration of $2.5 \mathrm{mmol} / \mathrm{L} .{ }^{16}$ Studies by Pereira et al suggest that a combination of certain metallic ions, including copper and zinc ions, reduces the erosive potential of some soft drinks. The addition of copper ions at the concentration of 15-30 $\mathrm{mmol} / \mathrm{L}$ to Sprite Zero ${ }^{\mathrm{TM}}$ decreases the enamel erosive potential by $22 \%-23 \% .{ }^{27}$ Copper and fluorine ions exhibit synergistic effects. In such combination, fluoride prevents the inhibitory effect of copper ions in remineralization and, at the same time, reduces demineralization to a greater extent than if acted alone. ${ }^{17}$ It appears that if you want to influence the copper content in the enamel and boost the resistance of this tissue, appropriate amounts of copper may be administered to pregnant women, already at an early stage of enamel mineralization during fetal development, and to children, when further tooth enamel mineralization stages occur. 
Both zinc and copper take part in many biochemical processes. ${ }^{23}$ As far as enamel is concerned, an excess of certain metal ions, including zinc and copper ions, may reduce the activity of some proteolytic enzymes and disturb amelogenesis. Some enzymes involved in the metabolism of extracellular components of the enamel matrix; for example, procollagen $\mathrm{N}$-proteinase, may be inactivated by $50 \%$ by copper at a concentration of 14-40 $\mu \mathrm{M}$; galactosylhydroxylysyl glucosyltransferase is inactivated both by zinc and copper at a concentration of $50-100 \mu \mathrm{M}$ and gelatinases A and $\mathrm{B}$ are inactivated at zinc and copper concentrations of around $100 \mu \mathrm{M} .28$

Zinc and copper have the ability to form stable complexes with proteins owing to so-called "zinc fingers" and take part in enzyme activation or inhibition. Zinc contained in enamel is one of the most potent inhibitors of kallikrein $4 .{ }^{12,29,30}$ Furthermore, zinc is also a component of certain metalloproteinases, including enamelysin which has the ability to bind two zinc and two calcium ions. ${ }^{31}$ Therefore, it may be assumed that the activities of both matrix metalloproteinase (MMP)-20 and kalikreine (KLK)-4 are affected considerably by an increase in zinc level. That is why, the increased zinc levels in some enamel layers in teeth free from any visible pathological changes may be related to the high activity of enamelysin. Prajapati et al found that the absence of MMP-20 affects the general morphology and structure of hydroxyapatite crystals. ${ }^{32}$ MMP-20 is also essential for creating a strong, normal dentino-enamel junction. ${ }^{33}$ Enamel formed without the participation of MMP-20 is hypoplastic, thin and has an abnormal prismatic structure. It has also been found that the stabilization of amorphous calcium phosphate and inhibition of its transformation into hydroxyapatite crystals occur in MMP-20 null enamel. ${ }^{32-36}$ The processing of amelogenin by MMP-20 is of key importance for the full enamel mineralization. ${ }^{32,37}$ Since KLK-4 and MMP-20 are interdependent and zinc is a KLK-4 inhibitor, the lack of activity of KLK-4 inactivated by zinc excess may affect an increased MMP-20 content and extend its activity. ${ }^{38}$ The lack of sufficient KLK-4 activity is associated with abnormal enamel mineralization. It would explain the relationship between the zinc content and a decreased or increased resistance of a particular enamel layer to pathological agents, since improper kallikrein 4 activity is related to abnormal enamel maturation and its reduced calcification. The studies have shown that enamel has normal spatial arrangement in the presence of kallikrein 4; however, its mineralization decreases with increasing depth. ${ }^{29}$

When analyzing the above information, a conclusion may be drawn that differences in the mineralization levels of particular enamel layers without any pathological changes are related to the zinc level at a particular depth, which depends on the copper level at the same time. The appropriate content of these minerals may determine whether the normal enamel undergoes the destructive effects of detrimental environment factors or not. The influence of genetic factors on this process is excluded, as deletions of AMELX and MMP-20 result in the formation of enamel with a porous surface which lacks a prismatic structure. ${ }^{38}$

\section{Conclusion}

- The lowest zinc and copper levels are found on the enamel surface of the teeth studied.

- The zinc and copper levels in the outer enamel layers result in increased content of unipolar minerals at deeper enamel layers.

- The content of the study elements determined may reflect the process of mineralization and maturation of enamel in the pre-eruption period.

\section{Author contributions}

All authors made substantial contributions to conception and design, acquisition of data, or analysis and interpretation of data; took part in drafting the article or revising it critically for important intellectual content; gave final approval of the version to be published; and agree to be accountable for all aspects of the work.

\section{Disclosure}

The authors report no conflicts of interest in this work.

\section{References}

1. Simmer JP, Hu JC. Dental enamel formation and its impact on clinical dentistry. J Dent Educ. 2001;65(9):896-905.

2. Bansal AK, Shetty DC, Bindal R, Pathak A. Amelogenin: a novel protein with diverse applications in genetic and molecular profiling. J Oral Maxillofac Pathol. 2012;16(3):395-399.

3. Chen H, Tang Z, Liu J, et al. Acellular synthesis of a human enamel-like microstructure. Adv Mater. 2006;18(14):1846-1851.

4. Zhu D, Paine ML, Luo W, Bringas P Jr, Snead ML. Altering biomineralization by protein design. J Biol Chem. 2006;281(30):21173-21182.

5. Chai H, Lee JJ, Kwon JY, Lucas PW, Lawn BR. A simple model for enamel fracture from margin cracks. Acta Biomater. 2009;5(5): 1663-1667

6. Fowler CE, Li M, Mann S, et al. Influence of surfactant assembly on the formation of calcium phosphate materials-a model for dental enamel formation. J Mater Chem. 2005;15:3317-3325.

7. Sa Y, Liang S, Ma X, et al. Compositional, structural and mechanical comparisons of normal enamel and hypomaturation enamel. Acta Biomater. 2014;10(12):5169-5177.

8. White SN, Luo W, Paine ML, Fong H, Sarikaya M, Snead ML. Biological organization of hydroxyapatite crystallites into a fibrous continuum toughens and controls anisotropy in human enamel. J Dent Res. 2001;80(1):321-326. 
9. Yahyazadehfar M, Bajaj D, Arola DD. Hidden contributions of the enamel rods on the fracture resistance of human teeth. Acta Biomater. 2013;9(1):4806-4814.

10. Barlett JD, Scobe Z, Lee DH, et al. A developmental comparison of matrix metalloproteinase-20 and amelogenin null mouse enamel. Eur J Oral Sci. 2006;114 (Suppl 1):18-23.

11. Sierpińska T, Orywal K, Kuc J, Golebiewska M, Szmitkowski M. Enamel mineral content in patients with severe tooth wear. Int J Prosthodont. 2013;26(5):423-428.

12. Gerlach RF, de Souza AP, Cury JA, Line SR. Effect of lead, cadmium and zinc on the activity of enamel matrix proteinases in vitro. Eur $J$ Oral Sci. 2000;108(4):327-334.

13. Lee SK, Kim YS, Lee SS, et al. Molecular cloning, chromosomal mapping, and characteristic expression in tooth organ of rat and mouse Krox-25. Genomics. 2004;83(2):243-253.

14. Lingawi H, Barbour ME, Lynch RJ, et al. Effect of zinc ions ( $\mathrm{Zn} \mathrm{2+)}$ hydroxyapatite dissolution kinetics studied using scanning microradiography. Caries Res. 2011;45:195.

15. Arora M, Kennedy BJ, Ryan CG, et al. The application of synchroton radiation induced X-ray emission in the measurement of zinc and lead in Wistar rat ameloblasts. Arch Oral Biol. 2007;52(10):938-944.

16. Brookes SJ, Shore RC, Robinson C, Wood SR, Kirkham J. Copper ions inhibit the demineralization of human enamel. Arch Oral Biol. 2003;48(1):25-30.

17. Abdullach AZ, Strafford SM, Brookes SJ, et al. The effect of copper on demineralization of dental enamel. J Dent Res. 2006;85:1011-1015.

18. Bjorklund $\mathrm{G}$. The role of zinc and copper in autism spectrum disoders. Acta Neurobiol Exp (Wars). 2013;73(2):225-236.

19. Smith CE. Cellular and chemical events during enamel maturation. Crit Rev Oral Biol Med. 1998;9(2):128-161.

20. ISO/TS 11405:2015: dentistry-testing of adhesion to tooth structure. Geneva: International Organization for Standardization; 2015.

21. Smith TM. Experimental determination of the periodicity of incremental features in enamel. J Anat. 2006;208(1):99-113.

22. Sabel N. Enamel of primary teeth-morphological and chemical aspects. Swed Dent J Suppl. 2012;222:1-77.

23. Bialek M, Zyska A. The biomedical role of zinc in the functioning of the human organism. Pol J Public Health. 2014;124(3):160-163.

24. Milosevic A, Dawson LJ. Salivary factors in vomiting bulimics with and without pathological tooth wear. Caries Res. 1996;30(5):361-366.

25. Grunke K, Stark HJ, Wennrich R, Franck U. Determination of traces of heavy metals ( $\mathrm{Mn}, \mathrm{Cu}, \mathrm{Zn}, \mathrm{Cd}$, and $\mathrm{Pb}$ ) in microsamples of teeth mineral by ETV-ICP-MS. Anal Bioanal Chem. 1996;354(5-6):633-635.
26. Brown CJ, Chenery SR, Smith B, et al. Environmental influences on trace element content of teeth - implications for desease and nutritional status. Arch Oral Biol. 2004;49(9):705-717.

27. Pereira HA, Leite Ade L, Italiani Fde M, Kato MT, Pessan JP, Buzalaf MA. Supplementation of soft drinks with metallic ions reduces dissolution of bovine enamel. J Appl Oral Sci. 2013;21(4):363-368.

28. de Souza AP, Gerlach RF, Line SR. Inhibition of human gingival gelatinases (MMP-2 and 9) by metal salts. Dent Mater. 2000;16(2): 103-108.

29. Yamakoshi Y, Yamakoshi F, Hu JC, Simmer JP. Charakterization of kallikrein-related peptidase 4 glycosylations. Eur J Oral Sci. 2011; 119 (Suppl 1):234-240.

30. Yoon H, Blaber SI, Li W, Scarisbrick IA, Blaber M. Activation profiles of human kallikrein-related peptidases by matrix metalloproteinases. Biol Chem. 2013;394(1):137-147.

31. Andreini C, Banci L, Bertini I, Luchinat C, Rosato A. Bioinformatic comparison of structures and homology-models of matrix metalloproteinases. J Proteome Res. 2004;3(1):21-31.

32. Prajapati S, Tao J, Ruan Q, De Yoreo JJ, Moradian-Oldak J. Matrix metalloproteinase-20 mediates dental enamel biomineralization by preventing protein occlusion inside apatite crystals. Biomaterials. 2016;75:260-270

33. Beniash E, Metzler RA, Lam RS, Gilbert PU. Transient amorphous calcium phosphate in forming enamel. J Struct Biol. 2009;166(2): 133-143.

34. Beniash E, Simmer JP, Margolis HC. The effect of recombinant mouse amelogenins on the formation and organization of hydroxyapatite crystals in vitro. J Struct Biol. 2005;149(2):182-190.

35. Kwak SY, Green S, Wiedemann-Bidlack FB, et al. Regulation of calcium phosphate formation by amelogenins under physiological conditions. Eur J Oral Sci. 2011;119 (Suppl 1):103-111.

36. Kwak SY, Wiedemann-Bidlack FB, Beniash E, et al. Role of 20-kDa amelogenin (P148) phosphorylation in calcium phosphate formation in vitro. J Biol Chem. 2009;284(28):18972-18979.

37. Simmer JP, Hu JC. Expression, structure, and function of enamel proteinases. Connect Tissue Res. 2002;43(2-3):441-449.

38. Bartlett JD, Yamakoshi Y, Simmer JP, Nanci A, Smith CE. MMP20 cleaves E-cadherin and influences ameloblast development. Cells Tissues Organs. 2011;194(2-4):222-226.
International Journal of Nanomedicine

\section{Publish your work in this journal}

The International Journal of Nanomedicine is an international, peerreviewed journal focusing on the application of nanotechnology in diagnostics, therapeutics, and drug delivery systems throughout the biomedical field. This journal is indexed on PubMed Central, MedLine, CAS, SciSearch ${ }^{\circledR}$, Current Contents ${ }^{\circledR} /$ Clinical Medicine,
Dovepress

Journal Citation Reports/Science Edition, EMBase, Scopus and the Elsevier Bibliographic databases. The manuscript management system is completely online and includes a very quick and fair peer-review system, which is all easy to use. Visit http://www.dovepress.com/ testimonials.php to read real quotes from published authors. 